\title{
タッピングタッチが唾液中オキシトシンの変化に及ぼす効果 その 5
}

\author{
一信頼感との関係— \\ ○大浦真一 (東海学院大学) - 福井義一 (甲南大学) - 中川一郎 (大阪経済大学) \\ キーワード : タッピングタッチ, オキシトシン, 信頼感
}

\section{目的}

タッピングタッチ（以下 TT）は, 指先の腹を使って軽く弾 ませるように左右交互に優しくタッチ寸ることを基本とした シンプルでホリスティックなケアの技法である(中川, 2004)。

TT は, 対人関係にも効果を示すことが特徴的であるが，こ の効果は, TT を受ける側だけではなく実施する側だけ（福井, 2016）でも，あるいは一人で実施するセルフタッピング（福 井他, 2017）でも，相互に実施する標準形に匹敵することが報 告されている。

TT による対人関係改善のメカニズム解明のために, 質問紙 （Fukui et al., 2017）と実験的手法（福井他, 2018）を用いて共 感性を測定し, TT 前後で変化を比較した結果, どちらの手法 を用いても, TT 後に一部の共感性が有意に改善していたこと が明らかになった。以上から, TT の対人関係改善効果の背景 に，主観的および客観的な共感性の高まりがあることが示唆 された。

さらに, こうした共感性改善のメカニズムを生理学的な見 地から検討するために, Fukui et al.（2019）は, TT 前後で唾 液中オキシトシン分泌量を比較した。その結果, TT を先に提 供してから受けるという順序（ケア先行群）ではオキシトシ ン分泌量が増加した一方で, 逆の順序 (被ケア先行群) では, オキシトシン分泌量に変化は見られないことが分かった。

ところで，オキシトシンは他者への信頼感形成にも寄与す るという報告がある（例, Bartz et al., 2010; Domes et al., 2007; Kosfeld et al., 2005）ことから, 本研究では, ケア先行群と被 ケア先行群について, TT 前後の TT のパートナーへの信頼感 の変化量を比較した。なお, ケア先行群の方が被ケア先行群 よりもパートナーへの信頼感の変化量が大きいという仮説を 設定した。

\section{方 法}

実験協力者: 成人 23 名が実験に参加し, 不備のなかった 18 名（男性 6 名, 女性 12 名）のデータを分析対象とした。平均 年齢は 45.50 歳 $(S D=12.23)$ であった。なお, データは, 福 井他 (2019), Fukui etal. (2019), 中川他 (2019), Nakagawa et al.（2019），Oura et al.（2019）と重複がある。

尺度 : TT のパートナーへの信頼感を測定するために, パート ナーへの信頼感尺度（福井, 2016）を用いて, パートナーへの 信頼感得点を得た。

手続き：最初に質問紙調査とオキシトシンの測定を目的とし た唾液採取を行った後, TT を実施した。途中の役割交代時に 唾液採取を行い, TT 実施後にも同じ内容の質問紙調査と唾液 採取を行った。なお, 質問紙には本研究で使用したもの以外 の尺度も含まれていた。TT の指導は, 開発者である第三発表
者が中心に行い, TT 協会の認定インストラクターである第 一，二発表者がサポートした。

倫理的配慮: 本研究は, 第二発表者の所属先のヒトを対象と した研究倫理審査委員会の承認を受けた。実験時には, 協力 者に対して調査の目的とプライバシーの保護について説明し， 文書で同意を得た。

利益相反開示: 発表に関連し, 開示すべき利益相反関係にあ る企業などはない。

\section{結 果}

パートナーへの信頼感について, TT 後の得点から TT 前の 得点を減算し, パートナーへの信頼感の変化量を求めた。

$\mathrm{TT}$ の実施順序 (ケア先行・被ケア先行) を独立変数, TT 前 後のパートナーへの信頼感の変化量を従属変数とした対応の ない $t$ 検定を実施した。その結果, 有意な群間差は見られな かったものの, ケア先行群の方が被ケア先行群よりもパート ナーへの信頼感の変化量が大きかった $(t(16)=1.45, p=.17, d$ $=.66)$ 。結果を Figure 1 に示した。

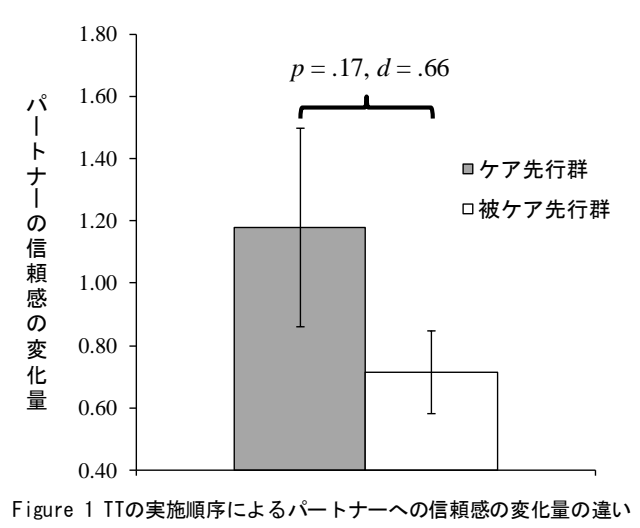

考 察

本研究の結果は，仮説を支持するものであった。つまり， 唾液中オキシトシン分泌量の大きいケア先行群の方が TT の パートナーへの信頼感の変化量が大きかった。以上より, TT によってパートナーへの信頼感が促進された要因の一つに, オキシトシン分泌量の増加が見られる可能性があることが示 唆された。

中川他（2019）によると, オキシトシン分泌量の増加は, ケア先行群が TTを受けているときに顕著であったことから, パートナーの信頼感においても, 同じ時点での変化を確認す る必要があるだろう。また, 本研究では効果量が中程度 $(d$ =.66）はあったものの, ケア先行群と被ケア先行群の間に有 意差は認められなかったことから, 結果の頑健性の確保のた めにも追試を重ねる必要がある。

(OURA Shin-ichi, FUKUI Yoshikazu, NAKAGAWA Ichiro) 